пСИХОЛОГИЯ

DOI: 10.17805/trudy.2015.6.2

\title{
ПСИХОФИЗИОЛОГИЧЕСКИЕ ХАРАКТЕРИСТИКИ ОБЪЕКТИВИЗАЦИИ ПРОЦЕССОВ ВНУШЕНИЯ
}

\author{
С. Ю. Баранов \\ (Московский гуманитарный университет)
}

\begin{abstract}
Аннотация: В статье рассматривается роль внушения в общественной жизни. Выделены психологические компоненты реализации внушения. Намечен цзелый ряд направлений для изучения внушаемости как свойства личности.
\end{abstract}

Ключевые слова: внушение; гипнотическое состояние; психофизиологические техники; Стенфордская шкала гипнабельности; SHSS; измененные состояния сознания; нейропсихологическая организация межполушарной активности

\section{PSYCHOPHYSIOLOGICAL CHARACTERISTICS OF THE OBJECTIFICATION OF SUGGESTION PROCESSES}

\author{
S. Yu. Baranov \\ (Moscow University for the Humanities)
}

Abstract: The article discusses the role of suggestion in public life, outlining the psychological components of implementing suggestion. Also identified area number of areas requiring additional research or experimentation aimed at studying suggestibility as a personality trait.

Keywords: suggestion; hypnotic state; intrusion in the mind; information infection; psychological techniques; Stanford hypnotic susceptibility scale (SHSS); altered state of consciousness; neuropsychological organization of hemispheric activity

\section{Введение}

Среди угроз или возможных угроз, связанных с военными действиями, экстремальными событиями, общественными трансформациями, личностными кризисами, болезнями, также существует опасность повышенной внушаемости населения. Считается, что социальное напряжение, экономическая ситуация, жизненные трудности и т. д. повышают уровень внушаемости человека. Мне хотелось бы остановиться на данной теме, которая не достаточно освещена в литературе. Необходимо отметить, что актуальность данной темы в своих работах, еще в начале XX века отмечал 
В. М. Бехтерев. Он впервые указал о существовании процесса внушения и наличия свойств внушаемости людей не применительно к медицинским или психологическим манипуляциям (Бехтерев, 2000: 141). Например, Б. Сидис пишет об этом: «Под внушением понимается вторжение в ум какой-либо идеи; встреченная большим или меньшим сопротивлением личности, она (личность) наконец принимается без критики и выполняется без осуждения, почти автоматично» (Сидис, 1902: 19). Вопрос о происхождении внушения получил в последнее время практическое значение в области психотерапии, психокоррекции, различных медитациях и аутогенных тренировок, а также благодаря изучению гипнотизма. Установлено, что внушение является актом гораздо более широким, чем гипнотическое внушение, так как оно проявляется в бодрствующем состоянии, наблюдается везде и всюду, то есть при весьма различных условиях.

Несмотря, на практическую важность внушения, его психологическая природа до сих пор представляется еще крайне мало изученной. Внушение часто входит в психическую сферу незаметно, без всякого насилия. Иногда, вызывая сопротивление, подвергаясь критике, но выполняется частично под контролем сознания. Но бывает и обратная ситуация, когда внушение входит в психическую сферу насильственным образом и принимается без всякой критики и внутренней борьбы, выполняясь автоматически. Например, под воздействием команды, приказа.

Нет надобности доказывать, что в отдельных случаях внушение действительно встречает сопротивление со стороны внушаемого лица, и, тем не менее, оно проникает в сознание, как паразит, почти насильственным способом. Есть даже такие термины, как «психологическая инфекция» или «информационная зараза», введенные В. М. Бехтеревым.

Так что это за механизмы, благодаря которым и проникает в нашу психику чужеродная, целенаправленная информация?

Чтобы ответить на этот вопрос, надо сначала разобраться с вопросом о том, что же такое внушение. Внушение - это одно из средств взаимодействия людей в процессе их обучения и деятельности. Характерная особенность внушения состоит в том, что оно оказывает влияние на психику и поведение человека незаметно. Реализуется в его жизнедеятельности в виде поступков, стремлений, мотивов и установок. Внушение стимулирует сознание человека, меняет его состояние и поведение, но сам человек к внушаемому содержанию не проявляет, ни критического, ни эффектного отношения (Бехтерев, 2000: 3-124; Гримак, 2000: 81-88; Куликов, 1965). Вообще говоря, внушение есть один из способов воздействия одних лиц на других, которое производится намеренно или ненамеренно со стороны воздействующего лица и которое может происходить или незаметно для внушаемого лица, или даже с его ведома и согласия. Как и по каким 
механизмам происходит воздействие, т. е. внушение? Внушение есть физиологическая особенность человека, присущая каждому, сложившаяся и закрепившаяся эволюционно. Это основа подчинение вожаку, следование за лидером, дабы выжить (страх смерти). «Пойду за лидером, он умнее, сильнее, опытнее, иначе умру голодной смертью или съедят другие». Т. е. речь идет о беспрекословном подчинении.

Среди психологических компонентов внушения можно выделить следующие:

1. Привлечь внимание к объекту,

2. Эмоциональный компонент, желательно из базовых (страх, голод, жажда, половое удовлетворение, ощущение счастья),

3. Отсутствие критического восприятия,

4. Повторение,

5. Подчинение,

6. Измененное состояние сознания.

Изучение данной проблемы позволяет наметить целый ряд направлений для дополнительных исследований, разработок, экспериментов и т. д. Среди них:

1) Разработка методов объективной оценки уровня внушаемости у населения (индивидуальных и групповых). На данный момент среди разных тестов и проб на определения уровня внушения используется тест Стенфордская шкала (SHSS). На наш взгляд, данный тест обладает существенным недостатком. А именно: испытуемый сам субъективно дает оценку уровню воздействия на него внушения. Потом путем сложения балов вычисляется значения уровня внушения. Но как человек может объективно оценить уровень внушения? Основываясь только на сугубо своих ощущениях? На наш взгляд, эта оценка недостаточно валидна. Весь вопрос заключается в следующем: «Как объективно измерить уровень внушения?»

Ведь внушение (по В. М. Бехтереву) сводится к непосредственному прививанию тех или других психических состояний от одного лица к другому, - прививанию, происходящему без участи воли (и внимания) воспринимающего лица и нередко даже без ясного с его стороны сознания. Т. е. какими же моделями или приборами можно провести замер внушения если внушение происходило без участи воли (и внимания)? Одним из методов исследования будет использован метод стабилометрии;

2) Определение условий и особенностей динамики протекания уровня внушаемости среди различных групп населения (профессиональных, гендорных, возрастных, индивидуально-личностных). Следует понять, у кого увеличивает, как увеличивает, насколько увеличивается, зачем увеличивается внушаемость; в каких показателях измеряется, как измеряет- 
ся. Ответов на эти вопросы пока нет;

3) Существует гипотеза, по которой восприятие информации по особому происходит у высоковнушаемых лиц (Гримак, Звоников, 1989: 47-51). Имеется ввиду, что высоковнушаемые люди имеют такую нейропсихологическую организацию межполушарной активности, при которой на них оказывает влияние не только вербальная, но и не вербальная информация (различного рода частотные характеристики, эффект резонанса, который при этом возникает а также воздействие подпороговой сенсорной информации и т. д.). Разработка, выяснение и создание экспериментальных моделей для проверки данной гипотезы производится в психофизиологической лаборатории университета Московского гуманитарного университета под руководством доктора медицинских наук, профессора, психотерапевта В. М. Звоникова;

4) Существующие процедуры внушения в обычном и измененном состоянии сознания (гипноз, медитация, аутогенная тренировка) предполагают добровольное участие пациента в данных процедурах. Эти модели годятся для изучения различных психотерапевтических и психокорекционных техник. Для этого необходимо наличие особых условий, а именно: общение один на один, в специально оборудованном кабинете без раздражающих факторов, с мягкими креслами, в форме неторопливого приятного разговора и главное - при наличии добровольного согласия пациента на данную процедуру.

В жизни происходи совершенно не так. Поэтому в настоящее время нами разрабатывается модель для экспериментальной проверки процедур внушения (передачи информации) без предварительного ознакомления пациента.

\section{СПИСОК ЛИТЕРАТУРЫ}

Бехтерев, В. М. (2000) Гипноз. Донецк: Сталкер.

Гримак, Л. П. (2000) Внушение - изначальный атрибут слова // Прикладная психология. № 6. С. 81-88.

Гримак, Л. П., Звоников, В. М. (1989) Моделирование функциональной асимметрии головного мозга с помощью гипнотического внушения // Аппаратура и методы исследования деятельности оператора. М. : Наука. C. 47-51.

Куликов, В. Н. (1965) Вопросы психологии внушения в общественной жизни // Проблемы общественной психологии / под ред. В. Н. Колобановского, В. Ф. Поршнева. М. : Мысль. С. 23-29.

Сидис, Б. (1902) Психология внушения. СПб.: Изд. Б. Звонарева. 
Баранов Сергей Юрьевич - аспирант кафедры общей психологии и истории психологии Московского гуманитарного университета. Адрес: 111395, Россия, г. Москва, ул. Юности, д. 5. Тел.: +7 (499) 374-67-20. Эл.адрес: vozmozhnosti@inbox.ru. Научный руководитель - д-р мед.н., проф. В.М.Звоников.

Baranov Sergey Yurievich, Postgraduate student, Department of general psychology and history of psychology, Moscow University for the Humanities. Postal address: 5 Yunosti St., 111395 Moscow, Russian Federation.Tel.: +7 (499) 374-67-20.E-mail: vozmozhnosti@inbox.ru. Research advisor: V. M.Zvonikov, Doctor of Medicine, Professor. 